\author{
DEPARTMENT OF THE INTERIOR \\ UNITED STATES GEOLOGICAL SURVEY
}

\title{
AEROMAGNETIC MAP OF PARTS OF THE HACKENSACK AND PATERSON QUADRANGLES, BERGEN AND PASSAIC COUNTIES, NEW JERSEY \\ By
}

P. W. Philbin and J. R. Kirby

GEOPHYSICAL INVESTIGATIONS

MAP GP-492

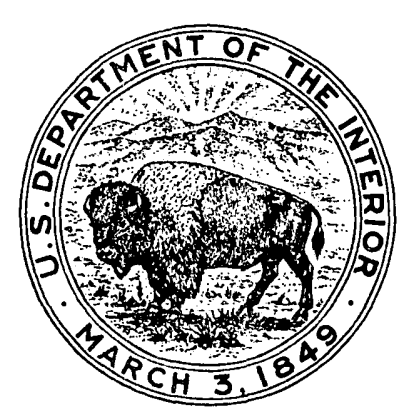

